\title{
Mammalian Tyrosinase: Effect of Ions on Enzyme Action ${ }^{1}$
}

\author{
Aaron Bunsen Lerner ? \\ From the Department of Dermatology, University of Michigan School of Medicine, \\ Ann Arbor, Michigan \\ Received October 8, 1951
}

\section{INTRODUCTION}

Recent investigations of mammalian tyrosinase have shown the relationship of some chemical and physical factors to tyrosinase activity $(1,2,3)$. Whereas the effect of temperature, $\mathrm{pH}$, lyophilization, oxidation-reduction potentials, and concentrations of enzyme and substrate have been studied, the effect of different ions and ionic concentration on tyrosinase activity has not been described. Hence, it was decided to study the influence of various electrolytes on mammalian tyrosinase. It was hoped that some information would be obtained regarding the mechanism of tyrosinase action as well as the means by which copper is bound to this enzyme. The inhibition of melanin formation by some metal ions was studied in particular.

\section{Experimental and Results}

Tyrosinase was prepared from the Harding-Passey mouse melanoma and lyophilized in a manner described previously $(1,2)$. The lyophilized preparations had been kept under vacuum for 3 years and, during most of that time, in a deep freeze. No loss of activity was apparent after this period. The lyophilized enzyme was suspended in distilled water for use. Enzymatic activity was determined manometrically by measurement of the oxygen uptake in the Warburg apparatus at $38^{\circ} \mathrm{C}$. and in $0.1 M$ sodium phosphate buffer at $\mathrm{pH} 6.8$. The substrate, $0.5 \mathrm{mg}$. L-tyrosine or $0.5 \mathrm{mg}$. (3,4-dihydroxyphenyl)- $\beta$-alanine (dopa), was added from the side arm of the Warburg vessel to the enzyme preparations after a 10 -min. equilibration of the solution at $38^{\circ} \mathrm{C}$. Approximately three units of tyrosinase were used in each reaction vessel.

1 'This investigation was supported in part by a research grant by the National Cancer Institute, of the National Institutes of Health, Public Health Service; and in part by a grant-in-aid from the American Cancer Society upon recommendation of the Committee on Growth of the National Research Council.

${ }^{2}$ With the technical assistance of Rosemarie Seguin. 


\section{TABLE I}

Effect of Univalent Cation Salts on Mammalian Tyrosinase

Reactions were carried out in $0.1 M$ sodium phosphate buffer at $\mathrm{pH} 6.8$ and $38^{\circ}$. Tyrosinase was prepared from the Harding-Passey mouse melanoma.

\begin{tabular}{|c|c|c|}
\hline Salt & $\begin{array}{c}\text { Tyrosine-tyrasinase } \\
\text { reaetion }\end{array}$ & $\begin{array}{l}\text { Dopa-tyrosinase } \\
\text { reaction }\end{array}$ \\
\hline $0.98 \mathrm{M}$ & $\%$ inhibition & $\%$ inhibition \\
\hline Lithium fluoride & $>98$ & 61.1 \\
\hline chloride & 34.6 & 53.8 \\
\hline bromide & 0 & 0 \\
\hline nitrate & 0 & 0 \\
\hline acetate & $>98$ & 80.3 \\
\hline sulfate & 16.5 & 45.6 \\
\hline Sodium fluoride & $>98$ & 74.9 \\
\hline $\begin{array}{l}\text { chloride } \\
\text { bromide }\end{array}$ & 69.5 & 52.9 \\
\hline bromide & 0 & 0 \\
\hline iodide & 0 & 0 \\
\hline nitrate & 0 & 0 \\
\hline acetate & $>98$ & 68.9 \\
\hline nitrite & $>98$ & 22.1 \\
\hline chlorate & 0 & 0 \\
\hline sulfate & 0 & 0 \\
\hline oxalate & 57.2 & 38.0 \\
\hline citrate & 0 & 0 \\
\hline tartrate & 12.5 & 0 \\
\hline arsenate & 0 & 0 \\
\hline phosphate & 0 & 0 \\
\hline Potassium fluoride & $>98$ & 49.5 \\
\hline chloride & 31.4 & 15.0 \\
\hline bromide & 0 & 0 \\
\hline iodide & 0 & 0 \\
\hline acetate & 73.8 & 40.4 \\
\hline $\begin{array}{l}\text { iodate } \\
(0.12 M)\end{array}$ & $>98$ & 98 \\
\hline chlorate & 0 & 0 \\
\hline sulfate & 0 & 0 \\
\hline persulfate & 65.6 & 61.1 \\
\hline oxalate & 66.1 & 49.8 \\
\hline phosphate & 0 & 0 \\
\hline $\begin{array}{l}\text { arsenite } \\
\left(10^{-4} M\right)\end{array}$ & 0 & 0 \\
\hline Ammonium chloride & 74.6 & 49.8 \\
\hline bromide & 0 & 0 \\
\hline iodide & 0 & 0 \\
\hline nitrate & 0 & 0 \\
\hline acetate & 55.6 & 80.9 \\
\hline sulfate & 0 & 0 \\
\hline $\begin{array}{l}\text { molybdate } \\
\left(10^{-4} M\right)\end{array}$ & 0 & 0 \\
\hline
\end{tabular}


Two different types of experiments were carried out. Salts of lithium, sodium, potassium, and ammonium are soluble in phosphate buffer. The effect of these ions on tyrosinase activity was determined simply by adding known amounts of these ions to the phosphate buffer. This approach was not feasible for the salts of most other metals because insoluble phosphate salts are formed. No effect was observed on the reactions when the concentration of the metals was so low that no visible precipitates with phosphate formed. To overcome this difficulty, copper-free tyrosinase was prepared in accordance with a method already described (2). Small quantities of the salts were then added to

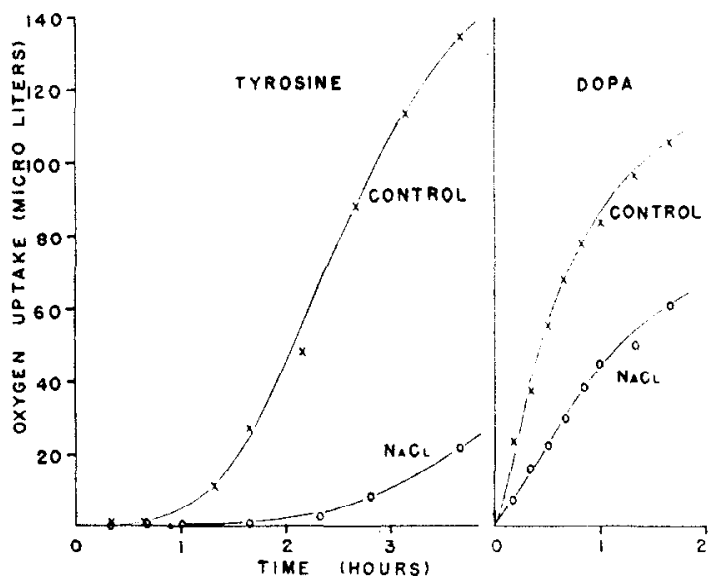

Fig. 1. Effect of $0.38 M$ sodium chloride on the tyrosine-tyrosinase and dopatyrosinase reactions in $0.1 M$ sodium phosphate buffer at $\mathrm{pH} 6.8$ and $38^{\circ}$. Five-tenths milligram tyrosine was used as substrate in each Warburg vessel as indicated. Total volume of each reaction mixture was $3 \mathrm{ml}$.

the copper-free enzyme along with copper ions. Sufficient copper was added so that $80-100 \%$ of the original enzymatic activity was restored. No insoluble phosphates formed with these small concentrations of metal ions.

At the onset it was found that varying the concentration of sodium or potassium phosphate buffer over a wide range $(0.05-0.5 M)$ at $\mathrm{pH}$ 6.8 did not produce any changes in enzyme action.

In Table $I$ are summarized the results of the action of lithium, sodium, potassium, and ammonium salts on the tyrosine-tyrosinase and dopa-tyrosinase reactions. Per cent inhibition of tyrosinase was 
obtained from the ratio of $(a)$ the difference in the maximum values of the oxygen uptake during a 10-min. interval between the control reaction and the salt inhibited reaction to $(b)$ the maximum value of the control tyrosinase reaction during the same period. The data obtained in a typical experiment are shown in Fig. 1.

The univalent cations $\mathrm{Li}^{+}, \mathrm{Na}^{+}$, and $\mathrm{NH}_{4}{ }^{+}$had no distinct effect on tyrosinase. Some of the potassium salts (fluoride, chloride, and acetate) may be less inhibitory than the corresponding lithium, sodium, or ammonium salts but more detailed studies would be required to establish this point. Several of the anions inhibited both reactions studied. Fluoride, chloride, and acetate consistently inhibited tyrosinase action regardless of the cation present. The results are in accord with the findings of Riley (4) that chloride ions inhibit tyrosinase activity of extracts from the Harding-Passey and Cloudman mouse melanomas. The mechanism by which these anions inhibit the reactions is not known. Sulfide and cyanide must be included in this group of inhibitory anions. They have been shown previously to inhibit tyrosinase (2) by removing the copper required for enzymatic activity.

Iodate, persulfate, and nitrite also inhibited the reactions. These substances are strong oxidizing and reducing agents and probably effect an oxidation-reduction potential in the reaction mixture unfavorable for tyrosinase action. No explanation is available at present for the inhibition exerted by lithium sulfate.

In general the anions are poor inhibitors of tyrosinase because high anion concentrations are required for inhibition. None of the salts accelerated the reactions.

When high concentrations of salts were added to tyrosinase in phosphate buffer, insoluble phosphates were formed. When the salt concentrations were reduced to $10^{-4} \mathrm{M}$, no visible precipitation occurred, but there was no change in tyrosinase action. It was then decided to determine whether any of the metal ions could compete with copper ions for the active centers on tyrosinase by adding various metal ions to copperfree tyrosinase concomitantly with copper ions. When tyrosinase was free of copper, approximately $10^{-5} M$ copper ions were required to restore $80-100 \%$ of the original activity. The salts listed in Table II were added to the apotyrosinase at the same time as copper sulfate. The final salt concentration was $10^{-4} M$ and the copper sulfate concentration was $10^{-5} M$. The substrate, $0.5 \mathrm{mg}$. dopa, was added to the reaction mixture after $10 \mathrm{~min}$. equilibration. When possible, the nitrates 
TABLE II

Metal Salts Added to Copper-free Tyrosinase
1. $\mathrm{Al}\left(\mathrm{NO}_{3}\right)_{3} \cdot 9 \mathrm{H}_{2} \mathrm{O}$
15. $\mathrm{Hg}\left(\mathrm{NO}_{3}\right)_{2} \cdot \mathrm{H}_{2} \mathrm{O}$
2. $\mathrm{AgNO}_{3}$
16. $\mathrm{Hg}\left(\mathrm{C}_{2} \mathrm{H}_{3} \mathrm{O}_{2}\right)_{2}$
3. $\mathrm{AgC}_{2} \mathrm{H}_{3} \mathrm{O}_{2}$
17. $\mathrm{HgNO}_{3} \cdot \mathrm{H}_{2} \mathrm{O}$
4. $\mathrm{AsCl}_{3}$
18. $\mathrm{Mg}\left(\mathrm{NO}_{3}\right)_{2} \cdot 6 \mathrm{H}_{2} \mathrm{O}$
5. $\mathrm{As}_{2} \mathrm{O}_{3}$
19. $\mathrm{MnSO}_{4} \cdot \mathrm{H}_{2} \mathrm{O}$
6. $\mathrm{HAuCl}_{4}$
20. $\left(\mathrm{NH}_{4}\right)^{6} \mathrm{Mo}_{7} \mathrm{O}_{24} \cdot 4 \mathrm{H}_{2} \mathrm{O}$
7. $\mathrm{Ba}\left(\mathrm{NO}_{3}\right)_{2}$
21. $\mathrm{Ni}\left(\mathrm{NO}_{3}\right)_{2} \cdot 6 \mathrm{H}_{2} \mathrm{O}$
8. $\mathrm{Be}\left(\mathrm{NO}_{3}\right)_{2}$
22. $\mathrm{Pb}\left(\mathrm{NO}_{3}\right)_{2}$
9. $\mathrm{Bi}\left(\mathrm{NO}_{3}\right)_{2} \cdot 5 \mathrm{H}_{2} \mathrm{O}$
23. $\mathrm{Sr}\left(\mathrm{NO}_{3}\right)_{2}$
10. $\mathrm{Cd}\left(\mathrm{NO}_{3}\right)_{2} \cdot 4 \mathrm{II}_{2} \mathrm{O}$
24. $\mathrm{Th}\left(\mathrm{NO}_{3}\right)_{4} \cdot 4 \mathrm{H}_{2} \mathrm{O}$
11. $\mathrm{Ce}\left(\mathrm{NO}_{3}\right)_{3} \cdot 6 \mathrm{H}_{2} \mathrm{O}$
25. $\mathrm{TiCl}_{4}$
12. $\mathrm{Co}\left(\mathrm{NO}_{3}\right)_{2} \cdot 6 \mathrm{H}_{2} \mathrm{O}$
26. $\mathrm{TlC}_{2} \mathrm{H}_{3} \mathrm{O}_{2}$
13. $\mathrm{Cr}\left(\mathrm{NO}_{3}\right)_{3} \cdot 9 \mathrm{H}_{2} \mathrm{O}$
27. $\mathrm{UO}_{2}\left(\mathrm{NO}_{3}\right)_{2}: 6 \mathrm{H}_{2} \mathrm{O}$
14. $\mathrm{Fe}\left(\mathrm{NO}_{3}\right)_{3} \cdot 9 \mathrm{H}_{2} \mathrm{O}$
28. $\mathrm{ZnSO}_{4} \cdot 7 \mathrm{H}_{2} \mathrm{O}$

and sulfates of the metals were used because these anions were without effect on tyrosinase action. In a few instances, as shown in Table II, the chlorides or acetates were used. However, it is possible that small amounts of these anions did not affect tyrosinase activity. Only high concentrations of chloride and acetate inhibited the reaction. Dopa and not tyrosine was used as a substrate because reconstituted tyrosinase is active on tyrosine only in the presence of small amounts of dopa. It was simpler to use dopa alone instead of a tyrosine-dopa mixture.

The results show that only mercury, silver, and gold ions inhibited enzyme action. Mercurous and mercuric ions had the same effect. Data from a typical experiment with these ions are shown in Table III.

Studies were then carried out in which the mercuric, silver, and gold ions were kept constant and the cupric ion concentration was varied. In other experiments the cupric ion concentration was kept constant

TABLE III

Effect of Mercury, Silver and Gold on Copper-Free Tyyrosinase

Ions of these metals were added to copper-free tyrosinase simultaneously with copper ions. Cation concentration was $10^{-4} M$ compared to $10^{-5} M$ for copper. Reactions were carried out in $0.1 \mathrm{M}$ sodium phosphate buffer at $\mathrm{pH} 6.8$ and $38^{\circ}$ with $8.45 \times 10^{-4} M$ dopa as substrate.

\begin{tabular}{rcccc} 
Time & \multicolumn{4}{c}{ Oxygen uptake, $\mu l}$. \\
min. & Control & Mercury & Silver & Gold \\
30 & 32.3 & 0 & 5.1 & 0 \\
60 & 54.3 & 0 & 20.4 & 0 \\
120 & 79.3 & 0 & 32.3 & 0
\end{tabular}


and the concentration of the other ions was varied. In Fig. 2 the reciprocal of the reaction rates is plotted against the reciprocal of the cupric ion concentration from data taken from experiments in the presence and absence of silver. Similarly shaped curves joining at the $1 / V$ axis were obtained with mercury and gold ions. Lineweaver and Burk (5) showed that for reversible competitive types of inhibition this form of graphic presentation results in straight lines that meet at the $1 / V$ axis.

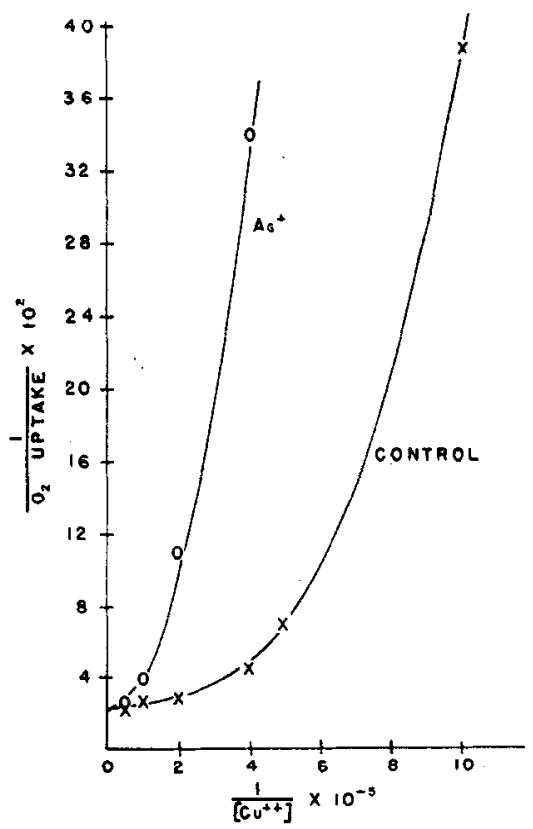

FIG. 2. Effect of $\mathrm{Ag}^{+}$on the reactivation of copper-free tyrosinase by the simultaneous addition of varying amounts of $\mathrm{Cu}^{++}$. $\mathrm{AgNO}_{3}, 5 \times 10^{-6} \mathrm{M}$, and copper-free tyrosinase were incubated in $0.1 M$ sodium phosphate buffer at $\mathrm{pH} 6.8$ and $38^{\circ}$ with $8.45 \times 10^{-4} M$ dopa as substrate. Total volume of each reaction mixture was $3 \mathrm{ml}$.

Cupric ions are not the natural substrate for tyrosinase, and for that reason the reactions here are somewhat different from those obtained by Lineweaver and Burk. In the experiments reported here, there were constant amounts of substrate, apoenzyme, and inhibitor with varying amounts of the metal ions (copper) which are required for the apoenzyme. In Fig. 2 it can be seen that the control and silver ion treated reactions intercept at the $1 / V$ axis but that straight-line relationships 
are not obtained. It is possible that the inhibition is competitive but only slowly reversible. This conclusion becomes more apparent when the reaction rates are plotted directly against the cupric ion concentration, as shown in Fig. 3. From these curves it is evident that high cupric ion concentration would be required to reverse the inhibited reactions completely. Once mercury or silver or gold becomes attached to the apotyrosinase, it is not easily replaced by cupric ions. Probably the reverse is also true, that is, once copper becomes attached to the enzymes it is replaced by ions of mereury, silver, and gold only with
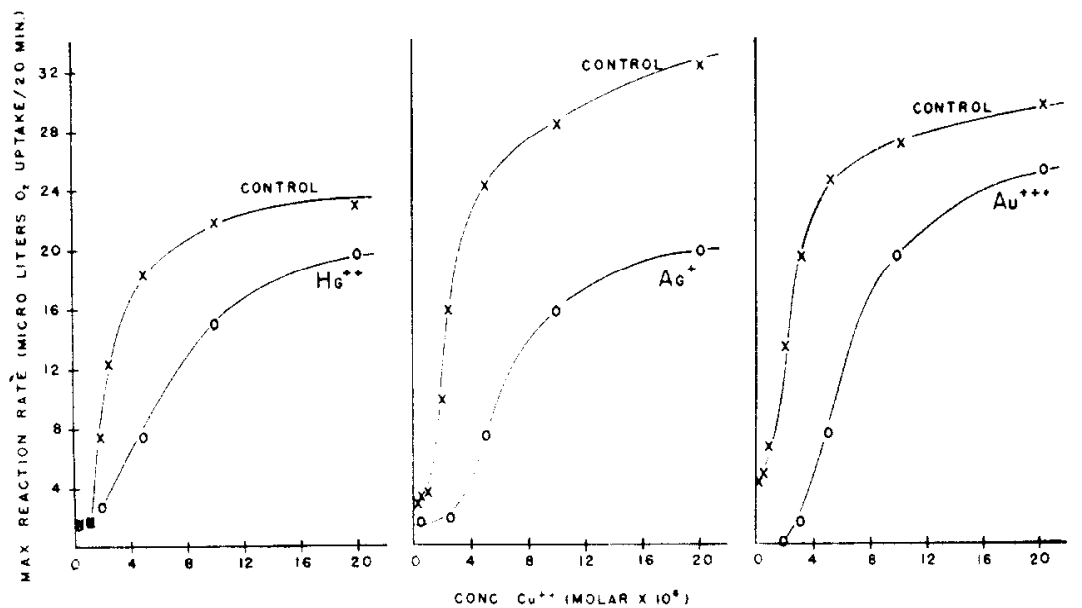

Fig. 3. Effect of $\mathrm{Hg}^{+}, \mathrm{Ag}^{++}$, and $\mathrm{Au}^{+++}$on the reactivation of copper-free tyrosinase by the simultaneous addition of varying amounts of $\mathrm{Cu}^{++} . \mathrm{Hg}\left(\mathrm{NO}_{3}\right)_{2}, 2.5$ $\times 10^{-4} \mathrm{M}$, or $5 \times 10^{-5} M \mathrm{AgNO}_{3}$ or $1.25 \times 10^{-4} \mathrm{M} \mathrm{HAuCl}_{4}$ was incubated with copper-free tyrosinase in $0.1 M$ sodium phosphate buffer at $\mathrm{pH} 6.8$ and $38^{\circ}$ with 8.45 $\times 10^{-4} \mathrm{M}$ dopa as substrate. Total volume of each reaction mixture was $3 \mathrm{ml}$.

difficulty. From the separation of the curves on the $V$-axis in Fig. 3, it appears that only auric ions might possibly replace copper present in minute amounts.

The results shown in Fig. 4 are a further indication that mercuric and auric ions, when present in sufficient concentration, can prevent any attachment of copper to the apotyrosinase. Silver ions are somewhat less effective. These findings substantiate the view that mercury, silver, and gold ions can compete with copper for apotyrosinase. The metal which first becomes bound to the apoenzyme, whether it be 
copper, mercury, silver, or gold, cannot be replaced easily by another metal.

\section{Nature of Copper-Apotyrosinase Bonding}

Arsenite ions are powerful reversible sulfhydryl inhibitors. To determine whether copper is bound to tyrosinase through a mercaptide linkage, arsenite ions were added to copper-free tyrosinase in 10 times the

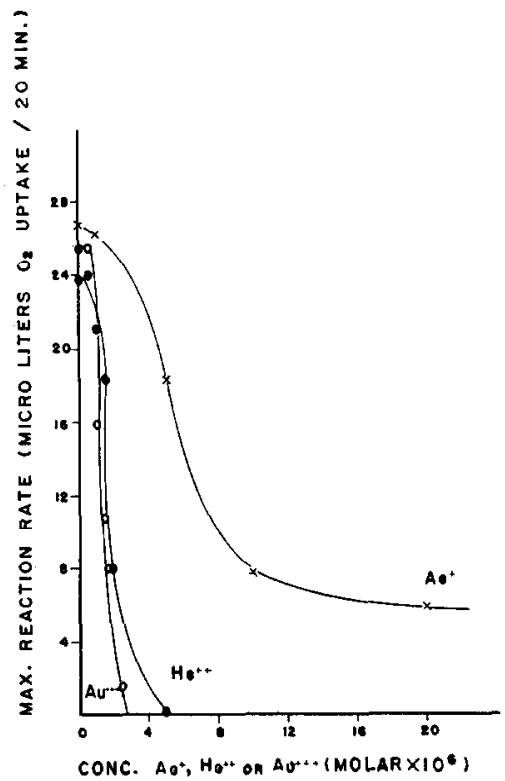

FIg. 4. Effect of varying amounts of $\mathrm{Hg}^{++}, \mathrm{Ag}^{+}$, and $\mathrm{Au}^{+++}$on the reactivation of copper-free tyrosinase by the addition of a fixed quantity of $\mathrm{Cu}^{++}$. Sufficient $\mathrm{Cu}^{++}$ was added to restore $80-100 \%$ of the original enzyme activity. Reactions were carried out in $0.1 \mathrm{M}$ sodium phosphate buffer at $\mathrm{pH} 6.8$ and $38^{\circ}$ with $8.45 \times 10^{-4} \mathrm{M}$ dopa as substrate. Total volume of each reaction mixture was $3 \mathrm{ml}$.

concentration of copper, which was added simultaneously. Sufficient copper was present to restore $80-100 \%$ of enzyme activity. Tyrosinase activity was restored as would be expected from the amount of cupric ions added. If copper were linked to a mercaptide group, arsenite should have prevented some restoration of tyrosinase action. Since this was not the case, copper is probably bound to tyrosinase by some linkage other than a mercaptide group. Further support of this view is obtained from earlier experiments. As much as 10 times the concen- 
tration of mercury and silver ions compared to copper ions was required to compete sufficiently with copper ions to inhibit tyrosinase. Yet, mercury and silver ions combine much more readily with sulfide groups than do copper ions.

It is of interest that three of the ions that bind with apotyrosinase, viz., copper, silver, and gold, are of the metals that make up the first subgroup in the periodic system of the elements. Further study of the binding action of these ions and also of mercury ions with nitrogen and oxygen groups may give insight as to the nature of the copper-apotyrosinase bonding.

\section{SUMMaRY}

1. The univalent cations $\mathrm{Li}^{+}, \mathrm{Na}^{+}, \mathrm{K}^{+}$, and $\mathrm{NH}_{4}^{+}$have no effect on tyrosinase action.

2. The anions, fluoride, chloride, acetate, and oxalate, consistently inhibit the tyrosine-tyrosinase and dopa-tyrosinase reactions. Iodate, persulfate, and nitrite also inhibit these reactions. Relatively large amounts of these anions are required to produce inhibition.

3. Of 24 metal ions tested, only mercury, silver, and gold can produce an inactive enzyme preparation. The ions compete with copper ions for active centers on apotyrosinase. These competitive inhibition reactions are only slowly reversible.

4. No cations or anions accelerate tyrosinase action.

5. Copper ions are not bound to tyrosinase by a mercaptide linkage.

\section{REFERENCES}

1. Lerner, A. B., Fitzpatrick, T. B., Calkins, E., and Summerson, W. H., $J$. Biol. Chem. 178, 185 (1949).

2. Lerner, A. B., Fitzpatrick, T. B., Calkins, E., and Summerson, W. H., $J$. Biol. Chem. 187, 793 (1950).

3. Lerner, A. B., and Fitzpatrick, T. B., Physiol. Revs. 30, 91 (1950).

4. Riley, V., Proc. Soc. Exptl. Biol. Med. 75, 644 (1950).

5. Lineweaver, H., and Burk, D., J. Am. Chem. Soc. 56, 658 (1934).

6. Barron, E. S. G., ANd Singer, T. P., J. Biol. Chem. 157, 221 (1945). 